\title{
Penentu transparansi pemerintah daerah: sebuah studi pada pemerintah daerah di Indonesia
}

\author{
Muhtar $^{1}$, Deni Ariyanto Putro ${ }^{2}$, Sutaryo ${ }^{3}$ \\ ${ }^{1}$ Program Studi Pendidikan Akuntansi, Universitas Sebelas Maret, Surakarta, Indonesia \\ ${ }^{2}$ Universitas Sebelas Maret dan Kementerian Keuangan Republik Indonesia \\ ${ }^{3}$ Program Studi Akuntansi, Universitas Sebelas Maret, Surakarta, Indonesia \\ e-mail: 'abujebi@gmail.com; ${ }^{2}$ deniariyantop@gmail.com; ${ }^{3}$ sutaryofebuns@gmail.com
}

\section{A R T IKEL I N F O}

Article history:

Available online

Keywords:

local government, transparency,

sociodemography, fiscal level, institutional, economy

\section{A B S T R A C T}

We analysed transparency in 394 local government in Indonesia during 2012-2015 period using sociodemography, fiscal, institutional, and economy factors. Transparency is assessed from the result of transparency assessment on local government level from the Commission of Information for Indonesia (Komisi Informasi Indonesia). We use the ratio of elder and human development index as demographic factors; fiscal capacity and leverage as fiscal factors; ideology and the level of local government head vistory as institutional factors; and unemployment level and gross domestic product as economic factors. The data is analysed using panel data regressiong. The analysis result shows that the ratio of elder has negative effect on transparency, but the level of fiscal decentralization, leverage, ideology, unemployment, and economic activity has positive effect on local government transparency in Indonesia. Meanwhile, human resource development and the level of local government head victory have no effect on local government transparency. These results imply that local government needs to increase the level of fiscal decentralization and economic activity at the local government level, as well as reducing the number of unemployment to optimize the transparency in their local government. Future research should try using another transparency measurement such as transparency in local government website and using another factor such as local government environment.

\begin{abstract}
A B S T R A K
Kami menganalisis transparansi pada 394 pemerintah daerah di Indonesia dalam kurun waktu 2012-2015 dengan menggunakan faktor sosiodemografi, fiskal, institusional, dan ekonomi. Transparansi menggunakan hasil penilaian tingkat transparansi pemerintah daerah dari Komisi Informasi Indonesia. Kami menggunakan rasio lansia dan indeks pembangunan manusia sebagai faktor sosiodemografi, kapasistas fiskal dan leverage sebagai faktor fiskal, ideologi dan tingkat kemenangan kepala daerah sebagai faktor institusional, dan tingkat pengangguran dan produk domestik bruto sebagai faktor ekonomi. Analisis data menggunakan dengan regresi data panel. Hasil analisis menunjukkan bahwa bahwa rasio lansia berpengaruh negatif terhadap transparansi, tetapi derajat desentralisasi fiskal, leverage, ideologi, tingkat pengangguran, dan aktivitas ekonomi berpengaruh positif terhadap transparansi pemerintah daerah di Indonesia. Adapun variabel indeks pembangunan manusia dan tingkat kemenangan kepala daerah tidak berpengaruh terhadap transparansi pemerintah daerah di Indonesia. Hasil penelitian berimplikasi pada pemerintah daerah untuk meningkatkan derajat desentralisasi fiskal dan aktivitas ekonomi daerah serta menurunkan tingkat pengangguran agar mengoptimalkan transparansi pemerintah daerah. Penelitian selajutnya dapat menggunakan pengukuran transparansi yang lain seperti transparansi dalam website pemerintah daerah dan menggunakan faktor lain seperti lingkungan pemerintah daerah.
\end{abstract}

\section{Pendahuluan}

Otonomi daerah yang telah diselenggarakan di Indonesia sebagai amanah ditetapkannya Undang-Undang Nomor 22 Tahun 1999 tentang Pemerintahan Daerah sebagaimana terakhir diubah dengan Undang-Undang Nomor 9 Tahun 2015 tentang Perubahan Kedua Atas Undang-Undang Nomor 23 Tahun 2014 tentang Pemerintahan Daerah (Republik Indonesia 1999, 2015b) telah memberikan kewenangan yang sangat luas bagi Pemerintah Daerah untuk 
mengelola "rumah tangga"-nya melalui konsep desentralisasi. Hal tersebut menjadi isu yang hangat di masyarakat mengingat bahwa saat ini terdapat peningkatan tuntutan dan perhatian terhadap praktik akuntansi yang dilakukan organisasi sektor publik. Selain itu, perkembangan tersebut juga selaras dengan munculnya tuntutan atas implementasi konsep New Public Management (NPM) demi mewujudkan good governance. Terlebih lingkungan sektor publik merupakan wilayah yang kompleks dan dipengaruhi oleh berbagai faktor, antara lain meliputi faktor ekonomi, politik, sosial, demografi, budaya, historis, kelembagaan, dan faktor-faktor lain.

Salah satu karakteristik utama dalam penerapan desentralisasi yang bertujuan untuk mencapai good governance adalah transparansi (Sheng 2009).Transparansi merupakan asas yang harus dipedomani dalam penyelenggaraan pemerintahan daerah (Republik Indonesia 2014). Adapun (Krina 2003), transparansi merupakan sebuah prinsip yang menjamin akses atau kebebasan bagi setiap orang untuk memperoleh informasi mengenai tata cara penyelenggaran pemerintahan, antara lain meliputi informasi mengenai proses perumusan sampai dengan implementasi, dan hasil yang dicapai atas kebijakan yang ditetapkan oleh pemerintah. Office of The United Nations High Commisioner For Human Right (OHCHR) menjelaskan bahwa dengan adanya transparansi dalam perumusan dan implementasi kebijakan publik dapat memberdayakan masyarakat dalam mengakses pelayanan sosial dan memberikan perlindungan terhadap hak-hak (hak ekonomi maupun sosial) mereka.

Perkembangan perhatian pemerintah terhadap transparansi mulai digalakkan dengan penetapan Instruksi Presiden Nomor 3 Tahun 2003 tentang Kebijakan dan Strategi Nasional Pengembangan E-Government, yang kemudian diikuti dengan Undang-Undang Nomor 14 Tahun 2008 tentang Keterbukaan Informasi Publik (UU KIP) dan berbagai peraturan turunannya yang menguatkan pentingnya pemenuhan transparansi oleh badan publik. Namun demikian, penerapan Undang-Undang KIP sampai dengan saat ini belum berjalan sesuai dengan harapan.Masih terdapat badan publik yang belum sepenuhnya menyediakan informasi sebagaimana diatur dan diamanahkan dalam UU KIP. Selain itu, beberapa sengketa yang timbul karena ada masalah dalam penyelesaian permohonan informasi publik dan tindak lanjut atas permohonan dimaksud belum ditindaklanjuti, walaupun sengketa tersebut pada dasarnya telah memiliki hasil keputusan (Indonesia Corruption Watch 2014). Temuan organisasi Antikorupsi mengenai implementasi KIP sampai tahun 2014 tersebut juga ditegaskan kembali oleh Trisulo selaku wakil Komisi Informasi yang menyatakan bahwa walaupun UU KIP telah berjalan selama hampir delapan tahun semenjak diterbitkan pada tahun 2008, namun pelaksanaan yang ada di masyarakat, badan-badan publik dimaksud masih belum sepenuhnya maksimal dalam memenuhi tuntutan UU KIP dan masih berstatus on progress untuk benar-benar mengimplementasikannya (Komisiinformasi.go.id 2016).

Evaluasi untuk mengetahui sejauh mana pelaksanaan transparansi badan publik, termasuk evaluasi transparansi pemerintahan daerah sebagai salah satu bentuk organisasi badan publik menjadi penting keberadaannya guna menjamin pengukuran atas sejauh mana implementasi UU KIP dan peraturan teknis turunannya sebenarnya telah dilaksanakan oleh Komisi Informasi. Namun, berdasarkan penelusuran awal terhadap hasil pemeringkatan keterbukaan informasi publik pada badan publik, khususnya badan publik pemerintah provinsi, pemerintah kabupaten, dan pemerintah kota diketahui bahwa pemerintah daerah belum sepenuhnya patuh terhadap amanah UU KIP. Selama tahun 2012-2015, pelaksanaan pemeringkatan keterbukaan informasi badan publik, tingkat keterbukaan badan publik masih berada pada posisi yang belum memuaskan, yaitu dengan ditunjukkan oleh rata-rata hasil penilaian hanya berkisar pada angka 50 dari rentang nilai maksimal 100 sebagai indikator bahwa pemerintah daerah telah mengimplementasikan UU KIP.

Tranparansi pemerintah telah menjadi fokus dalam beberapa penelitian terdahulu baik di indonesia (Martani et al. 2013; Sofia dan Bagus 2013) maupun non Indonesia (Serrano-Cinca et al. 2009; Behn et al. 2010; Guillamon et al. 2011; Bolivar dan Antonio 2013; Sol 2013; Tavares dan Nuno 2014; Araujo dan Fransisco 2016). Beberapa faktor telah digunakan sebagai determinan transparansi keuangan, seperti ukuran, implementasi e-government, tingkat kehidupan dan pendidikan (Serrano-Cinca et al. 2009), faktor politik dan sosio ekonomi (Wehner dan Paolo 2013; Guillamon et al. 2011), ekonomi, sosial, dan institusional (Sol 2013), kapabilitas keuangan pemerintah (Sofia dan Bagus 2013), kinerja keuangan (Martani et al. 2013), penawaran dan permintaan informasi (Tavares dan Nuno 2014; Araujo dan Fransisco 2016).

Penelitian ini fokus pada menggunakan atribut sosiodemografi, fiskal, institusional, dan ekonomi dalam suatu pemerintahan daerah guna memperoleh bukti empiris mengenai pengaruhnya terhadap transparansi pemerintah daerah di Indonesia. Penelitian ini menggunakan hasil pemeringkatan informasi publik pada badan publik pemerintah provinsi, pemerintah kabupaten, dan pemerintah kota yang telah dilaksanakan oleh Komisi Informasi karena dianggap merupakan hasil penilaian yang representatif dan komprehensif terkait dengan keterbukaan informasi publik sebagaimana diamanahkan dalam UU KIP. Hasil penelitian memberi kontribusi sebagai tambahan dan penguat literatur terkait dengan transparansi keuangan pemerintah dan sebagai tambahan informasi dalam pengambilan kebijakan oleh pemrintah daerah dan Komisi Informasi selaku regulator dalam rangka meningkatkan akuntabilitas dan transparansi pemerintah daerah sebagaimana tuntutan dari pelaksanaan desentralisasi dan otonomi daerah di Indonesia. 


\section{Tinjauan Pustaka dan Perumusan Hipotesis}

\section{Teori Legitimasi}

Dowling dan Jeffrey (1975) telah menyusun suatu rerangka konseptual guna memberikan gambaran hubungan antara nilai-nilai sosial dan perilaku organisasi. Konsep tersebut memunculkan teori legitimasi dalam organisasi yang akan selalu memunculkan dinamika perilaku organisasi sepanjang berdirinya suatu organisasi, khususnya organisasi formal. Legitimasi didefinisikan oleh Suchman (1995) sebagai suatu persepsi atau asumsi umum bahwa tindakan yang dilakukan oleh entitas adalah tepat atau sesuai dengan beberapa sistem yang ada dan dibangun berdasarkan norma sosial, nilai-nilai keyakinan. Legitimasi menurut Colquhoun (2013) pada umumnya dibahas dalam literatur-literatur mengenai akuntansi sektor publik. Sektor publik dimaksud meliputi entitas berhubunngan dengan pelayanan dan pemenuhan hak publik (Mardiasmo 2002).

Suchman (1995) menambahkan bahwa pada dasarnya tidak pernah ada organisasi yang dapat benarbenar memuaskan semua pihak dan mempunyai konkruen sistem sosial, namun organisasi dapat selalu berusaha menjaga legitimasi baik dengan meningkatkan, menjaga, maupun memperbaiki legitimasi demi kelangsungan organisasi. Dalam keadaan tersebut, organisasi mau tidak mau akan selalu berusaha untuk meningkatkan dan menjaga legitimasi, antara lain dengan menyesuaikan output, tujuan dan metode operasinya sehingga sesuai dengan legitimasi yang berlaku ataupun melakukan komunikasi sebagaimana dijelaskan Dowling dan Pfeffer (1975). Salah satu hal yang dapat menghasilkan legitimasi bagi suatu organisasi, termasuk pemerintah daerah adalah transparansi (Licht et al. 2014), yang diwujudkan baik transparansi dalam proses maupun transparansi dalam rasional.

\section{Transparansi Pemerintah Daerah di Indonesia}

Menurut Sheng (2009), transparansi berarti bahwa keputusan yang diambil dan penegakannya dilakukan sesuai dengan aturan. Hal ini juga berarti bahwa informasi tersedia secara bebas dan langsung dapat diakses oleh mereka yang dipengaruhi oleh keputusan dan penegakan hukum atas informasi dimaksud. Transparansi juga dapat bermakna bahwa tersedia informasi cukup dalam bentuk dan media yang dapat dipahami para pemakainya. Pengaturan mengenai transparansi di Indonesia mulai dilaksanakan dengan ditetapkannya UU KIP. UU tersebut mengatur mengenai pengelolaan informasi publik pada badan publik, termasuk menegaskan bahwa pemerintah daerah sebagai lembaga eksekutif dan penyelenggara daerah yang bertanggung jawab terhadap penyelenggaraan daerah merupakan salah satu badan publik yang wajib mengimplementasikan UU KIP. UU KIP juga menjelaskan bahwa pada dasarnya setiap orang atau publik memiliki hak untuk mendapatkan berbagai informasi publik dengan tetap berpedoman kepada UU KIP.

Guna melaksanakan UU KIP dan berbagai aturan pelaksanaannya dibentuk Komisi Informasi. Komisi tersebut juga dapat melakukan evaluasi dalam bentuk antara lain melalui penilaian saat sosialisasi, kuesioner penelitian transparansi, monitoring dan evaluasi, atau melalui visitasi dengan mendatangi langsung masingmasing badan publik yang dilakukan penilaian guna mengetahui dan menilai sejauh mana implementasi UU KIP dan peraturan turunannya yang telah dilaksanakan oleh badan publik, salah satunya adalah evaluasi yang dilakukan terhadap pemerintah daerah pemerintah provinsi, pemerintah kabupaten, dan pemerintah kota) dalam memberikan layanan informasi publik.

Sebagaimana dijelaskan oleh Dowling dan Jeffrey (1975) bahwa organisasi, termasuk pemerintah daerah akan selalu berusaha menjaga legitimasi yang dimiliki, yaitu salah satunya dengan melaksanakan kewajiban transparansi (Licht et al. 2014). Namun, transparansi pemerintah daerah sebagai salah satu organisasi sektor publik dimaksud sebagaimana dijelaskan Mardiasmo (2002) dipengaruhi oleh berbagai faktor, bukan hanya faktor ekonomi, melainkan juga faktor sosial, historis, politik, kelembagaan, budaya, demografi, dan faktor lainnya. Selain itu, proses alokasi sumber daya fiskal juga memperngaruhi organisasi sektor publik Dowling dan Pfeffer (1975).

\section{Sosiodemografi dan Transparansi Pemerintah Daerah}

Menurut Merriam Webster (2016), sosiodemografi berarti dari, berhubungan dengan, atau melibatkan kombinasi faktor sosial dan demografis. Faktor sosial dan demografis tersebut sebagaimana dijelaskan oleh Mardiasmo (2002) merupakan salah satu faktor yang berkaitan dan berpengaruh terhadap sektor publik, salah satunya guna memenuhi tuntutan transparansi. Dimensi sosial demografi dalam penelitian mengenai transparansi antara lain variabel rasio lansia dan karakteristik masyarakat (umur dan tingkat pendidikan).

Menurut Undang-Undang Nomor 13 Tahun 1998 (Republik Indonesia 1998) tentang Kesejahteraan Lanjut Usia, lanjut usia (lansia) adalah seseorang yang telah mencapai usia enam puluh tahun ke atas. Rasio penduduk lansia merupakan gambaran perbandingan antara jumlah penduduk lansia pemerintah daerah dengan jumlah 
seluruh penduduk pemerintah daerah (Badan Pusat Statistik 2015). Esterller-More dan Jose (2012) menyatakan bahwa terdapat korelasi antara persentase penduduk lansia dengan tingkat transparansi pemerintah daerah.

Indeks Pembangunan Manusia (IPM) menurut Badan Pusat Statistik merupakan suatu ukuran yang digunakan untuk menjelaskan bagaimana penduduk dapat mengakses hasil pembangunan untuk kemudian dapat digunakan dalam rangka memperoleh pendapatan, kesehatan, pendidikan, dan berbagai aspek kehidupan lainnya. Adzani dan Dwi (2014) menyebutkan bahwa semakin kondisi IPM yang semakin bertumbuh dan membaik akan meningkatkan dan memperbaiki tingkat kualitas kehidupan, baik kualitas kehidupan masyarakat maupun kualitas pemerintahan secara keseluruhan. Adapun Piotrowski dan Gregg (2007) mendapatkan hasil penelitian berupa adanya pengaruh umur, tingkat pendidikan dan keterlibatan dalam politik terhadap permintaan atas transparansi pemerintahan, umur dan tingkat pendidikan merupakan komponen IPM.

\section{Fiskal dan Transparansi Pemerintah Daerah}

Fiskal menurut Merriam Webster (2016a) adalah berkaitan dengan perpajakan, pendapatan masyarakat, atau utang publik (kebijakan fiskal) atau terkait dengan masalah keuangan.Adapun definisi kebijakan fiskal menurut Mardiasmo (2002) adalah usaha yang dilakukan oleh pemerintah untuk mempengaruhi keadaan ekonomi melalui sistem pengeluaran atau sistem perpajakan untuk mencapai tujuan tertentu.Dimensi fiskal yang digunakan dalam penelitian mengenai transparansi, antara lain dengan menggunakan variabel derajat desentralisasi fiskal dan leverage.

Peraturan Pemerintah Nomor 58 Tahun 2005 tentang Pengelolaan Keuangan Daerah Pasal 20 menjabarkan bahwa struktur Anggaran Pendapatan dan Belanja Daerah (APBD) terdiri atas 3 komponen dasar, yaitu pendapatan daerah, belanja daerah, dan pembiayaan daerah. Mahmudi (2016) menyatakan bahwa derajat desentralisasi fiskal menunjukkan derajat kontribusi Pendapatan Asli Daerah (PAD) terhadap total penerimaan daerah. Adapun Wahyudi dan Laila (2013) dalam penelitiannya memperoleh hasil bahwa terdapat korelasi positif antara kualitas derajat desentralisasi dan kualitas pemerintahan. Hal tersebut merupakan media yang mendorong pemerintah untuk mengkomunikasikan informasi mengenai perbaikan kualitas pemerintahan secara transparan sebagai bukti bahwa operasional pemerintahan telah diperbaiki, mengingat tranparansi mengenai informasi dimaksud dapat menghasilkan legitimasi bagi pemerintah (Dowling dan Pfeffer, 1975; Licht et al., 2014).

Guna membiayai kebutuhan belanja daerah, selain berasal dari pendapatan daerah, pemerintah daerah juga melakukan pinjaman daerah sesuai aturan (Republik Indonesia 2011, 2005). Mahmudi (2016) menjelaskan bahwa salah satu bentuk analisis rasio keuangan pemerintah daerah adalah rasio kewajiban (leverage ratio). Lebih lanjut, rasio tersebut merupakan salah hal penting yang menjadi perhatian pihak-pihak yang terkait dengan pemerintah daerah, termasuk bagi masyarakat guna mengkonfirmasi proses dan kondisi pemerintah daerah, mengingat sistem yang harus dilaksanakan sesuai UU. Sol (2013) dan Perona (2014) menggunakan variabel utang dalam penelitian untuk mengetahui hubungannya dengan transparansi.

\section{Institusional dan Transparansi Pemerintah Daerah}

Menurut Kamus Besar Bahasa Indonesia (2016), instituional adalah mengenai lembaga atau bersifat kelembagaan. UUD 1945, Pasal 18 menjabarkan bahwa menjabarkan bahwa Negara Kesatuan Republik Indonesia (NKRI) terdapat pembagian wilayah Indonesia menjadi daerah provinsi, kabupaten dan kota. Tiap daerah dimaksud mempunyai dan menjalankan suatu pemerintahan daerah masing-masing. Faktor institusional yang digunakan dalam penelitian mengenai transparansi antara lain berupa variabel ideologi dan tingkat kemenangan kepala daerah dalam pemilu.

Menurut $\mathrm{KBBI}$, ideologi salah satunya dapat dimaknai sebagai cara berpikir seseorang atau suatu golongan, atau paham, teori, dan tujuan yang merupakan satu program sosial politik. Aturan mengenai pemilihan umum dan partai politik, salah satunya Undang-Undang Nomor 8 Tahun 2015 (Republik Indonesia 2015a) mengatur bahwa pengusulan calon kepala daerah dapat menjadi peserta pemilihan ketika diusulkan oleh satu partai politik, atau diusulkan oleh beberapa/gabungan beberapa partai politik, atau calon kepala daerah tersebut mendaftarkan diri dan memenuhi pengajuan dirinya sebagai calon independen dalam pemilihan kepala daerah di Komisi Pemilihan Umum (KPU) berkenaan. Dengan adanya alternatif pengajuan calon kepala daerah dimaksud, dinamika politik yang ada saat ini ditindaklanjuti oleh partai politik dengan melakukan koalisi dan negosiasi (Redjo 2010), di antaranya berupa koalisi atas tiap-tiap calon kepala daerah.

Undang-Undang Dasar 1945, Pasal 18 menjelaskan bahwa pemilihan kepala daerah, dilaksanakan secara demokratis. UU Pemilihan Kepala Daerah, Pasal 109 menjelaskan bahwa pasangan yang ditetapkan sebagai calon kepala daerah terpilih adalah calon kepala daerah yang memperoleh suara terbanyak dalam pemilihan kepala daerah dan apabila persentase perhitungan atas diperoleh hasil yang sama, penentuan calon kepala daerah terpilih didasarkan pada tingkat persebaran suara yang lebih merata di seluruh wilayah pelaksanaan pemilihan kepala daerah. 


\section{Ekonomi dan Transparansi Pemerintah Daerah}

Menurut Kamus Bisnis (2016b), ekonomi adalah seluruh jaringan produsen, distributor, dan konsumen barang dan jasa dalam suatu komunitas lokal, regional, maupun nasional. Beberapa penelitian yang menggunakan dimensi ekonomi dalam penelitian transparansi adalah Sol (2013) dan Guillamon et al. (2011), dengan variabel tingkat pengangguran dan aktivitas ekonomi. Menurut BPS, Tingkat Pengangguran Terbuka (TPT) adalah persentase jumlah pengangguran terhadap jumlah angkatan kerja. Lebih lanjut, penganggur terbuka yang termasuk dalam klasifikasi perhitungan TPT suatu pemerintah daerah merupakan penduduk angkatan kerja di suatu pemerintah daerah yang termasuk ke dalam penduduk yang tidak memiliki pekerjaan karena ketidakpercayaan atas pekerjaan yang mungkin dapat diperoleh, penduduk yang sedang mencari pekerjaan karena belum memiliki pekerjaan tertentu, penduduk yang sedang berusaha untuk mulai mempersiapkan usaha sebagai bentuk pekerjaannya, dan penduduk yang sedang jadwal mulai bekerja atas pekerjaan yang telah didapatkannya. Caamano-Alegre et al. (2011) menemukan bahwa tingkat pengangguran berpengaruh negatif terhadap transparansi.

Aktivitas ekonomi menurut Kamus Bisnis (2016) adalah aktivitas yang melibatkan produksi, distribusi, dan konsumsi barang dan jasa di semua tingkatan dalam masyarakat. Produk Domestik Bruto (PDB) merupakan salah satu cara untuk menilai kegiatan ekonomi dan tingkat aktivitas ekonomi saat ini dan perkiraan tingkat aktivitas ekonomi di masa depan yang secara signifikan dapat berdampak terhadap aktivitas bisnis dan keuntungan, serta inflasi dan suku bunga. Produk Domestik Regional Bruto (PDRB) merupakan indikator yang lebih tepat digunakan untuk melihat kegiatan dan aktivitas ekonomi suatu daerah.

\section{Tinjauan Pustaka dan Perumusan Hipotesis}

Penduduk lansia merupakan suatu bagian dari penduduk di suatu daerah. UU Nomor 13 Tahun 1988 menjelaskan bahwa lansia adalah seseorang yang telah mencapai usia enam puluh tahun ke atas. Pada usia lansia tersebut, penduduk akan berusaha menikmati masa tua atau telah memasuki masa pensiun dengan tabungan atau hal lain yang telah dipersiapkan sebelumnya, namun ternyata masih terdapat kesalahan yang dilakukan oleh masyarakat, termasuk lansia di Indonesia, yaitu hanya mempersiapkan kebutuhan pensiun untuk diri mereka sendiri dan bukan persiapan untuk kebutuhan yang harus dicukupi untuk memenuhi kebutuhan diri mereka bersama pasangan (Kontan.co.id 2014). Pada keadaan tersebut, penduduk golongan lansia diduga akan menjadi lebih menaruh perhatian akan pengelolaan daerah guna memastikan bahwa kehidupan mereka tetap terjamin dan tidak ada penyalanggunaan pengelolaan daerah yang dapat berakibat buruk terhadap masa tua mereka. Meningkatnya perhatian tersebut mendorong pemerintah daerah untuk terus berusaha mengkomunikasikan keadaan pemerintahan daerah yang baik sebagai salah satu cara menjaga legitimasi yang pemerintah daerah miliki (Licht et al. 2014), mengingat lansia merupakan salah satu bagian dari masyarakat suatu daerah. Esterller-More dan Jose (2012) mendapati bahwa pemerintah daerah dengan tingkat persentase lansia yang tinggi berkorelasi dengan tingginya transparansi. Piotrowski dan Gregg (2007) juga memperoleh hasil yang serupa bahwa orang tua tampak lebih cenderung menginginkan transparansi daripada orang yang lebih muda. Berdasarkan uraian tersebut, hipotesis penelitian ini dirumuskan sebagai berikut:

$\mathrm{H}_{1}$ : Rasio lansia berpengaruh positif terhadap transparansi pemerintah daerah di Indonesia.

BPS menyebutkan bahwa IPM merupakan suatu ukuran yang digunakan untuk menjelaskan bagaimana penduduk dapat mengakses hasil pembangunan untuk kemudian dapat digunakan dalam rangka memperoleh pendapatan, kesehatan, pendidikan, dan berbagai aspek kehidupan lainnya. Adzani dan Dwi (2014) menyebutkan bahwa semakin tinggi IPM akan meningkatkan dan memperbaiki tingkat kualitas kehidupan, baik kualitas kehidupan masyarakat maupun kualitas pemerintahan secara keseluruhan. Piotrowski dan Gregg (2007) mendapati bahwa umur dan tingkat pendidikan terkait dengan permintaan atas transparansi pemerintahan. Umur dan tingkat pendidikan tersebut pada dasarnya termasuk dalam kompenen yang dinilai dalam IPM. Dengan semakin tingginya kualitas hidup yang selaras dengan meningkatnya IPM dimaksud diduga semakin meningkatkan pemahaman masyarakat tentang sistem nilai sosial yang seharusnya dilaksanakan oleh pemerintah dalam rangka penyelenggaraan pemerintahan. Selanjutnya diduga meningkatkan perhatian dan tuntutan masyarakat atas penyajian informasi mengenai pengelolaan pemerintahan dan kebijakan publik yang sesuai dengan sistem nilai yang ada. Kondisi tersebut mendorong pemerintah untuk berusaha menjaga legitimasi (Dowling dan Pfeffer, 1975) yang ada dengan menjaga kualitas penyelenggaraan pemerintahan, yang artinya menjalankan pemerintahan sebagaimana aturan yang telah ditetapkan dan berusaha memenuhi tuntutan untuk mengkomunikasikan pengelolaan pemerintahan dan kebijakan publik secara transparan (Licht et al. 2014). Berdasarkan uraian tersebut, hipotesis penelitian ini dirumuskan sebagai berikut:

$\mathrm{H}_{2}$ : Indeks Pembangunan Manusia (IPM) berpengaruh positif terhadap transparansi pemerintah daerah di Indonesia. 
Salah satu alat untuk menghitung ukuran rasio keuangan, khususnya guna mengukur elemen pendapatan suatu pemerintah daerah adalah derajat desentralisasi fiskal. Mahmudi (2016) menyatakan bahwa derajat desentralisasi fiskal tersebut memperlihatkan tingkat derajat kontribusi PAD terhadap total pendapatan daerah suatu pemerintah daerah. Perhitungan derajat desentralisasi fiskal dimaksud dilakukan dengan membagi PAD dengan total pendapatan daerah. Wahyudi dan Laila (2013) menyatakan bahwa terdapat korelasi positif antara kualitas derajat desentralisasi dan kualitas pemerintahan. Semakin besar derajat desentralisasi fiskal tersebut diduga semakin memperlihatkan bahwa kualitas pemerintahan menjadi lebih baik dalam memaksimalkan segala sumber daya yang dimiliki oleh pemerintah daerah guna menunjang pendapatan daerah. Hal tersebut merupakan hal yang ingin selalu dicapai oleh pemerintah daerah sebagai organisasi, Kuswanto (2012) menjelaskan bahwa kualitas pemerintahan yang lebih dimaksud merupakan harapan dan keyakinan masyarakat dalam pelaksanaan good governance yang harus dilakukan secara tepat dan sesuai oleh organisasi pemerintahan. Hal tersebut media yang mendorong pemerintah untuk mengkomunikasikan informasi mengenai perbaikan kualitas pemerintahan secara transparan sebagai bukti bahwa operasional pemerintahan telah diperbaiki, mengingat tranparansi mengenai informasi dimaksud dapat menghasilkan legitimasi bagi pemerintah (Dowling dan Pfeffer, 1975; Licht et al., 2014). Berdasarkan uraian tersebut, hipotesis penelitian ini dirumuskan sebagai berikut:

$\mathrm{H}_{3}$ : Derajat desentralisasi fiskal berpengaruh positif terhadap transparansi pemerintah daerah di Indonesia.

Pembiayaan daerah merupakan salah satu struktur APBD. Pembiayaan tersebut dilakukan ketika ada kebutuhan belanja daerah yang tidak dapat dipenuhi melalui pendapatan daerah sehingga salah satu jalan yang dapat dilakukan pemerintah daerah untuk menutup kekurangan tersebut adalah dengan melakukan penerimaan pembiayaan daerah dalam bentuk melakukan pinjaman daerah. Pinjaman daerah adalah semua transaksi yang mengakibatkan daerah menerima sejumlah uang atau menerima manfaat yang bernilai uang dari pihak lain sehingga daerah tersebut dibebani kewajiban untuk membayar kembali. Selanjutnya, salah satu analisis rasio keuangan pemerintah daerah yang dijelaskan oleh Mahmudi (2016) adalah rasio kewajiban (leverage ratio). Rasio leverage merupakan salah hal penting yang menjadi perhatian untuk mengukur kemampuan pemerintah daerah untuk melunasi kewajibannya. Semakin tinggi tingkat kewajiban yang dimiliki dengan tidak diimbangi oleh aset dapat diberdayakan guna melunasi kewajiban dimaksud, semakin membuat kekhawatiran di masyarakat bahwa kondisi pengelolaan utang pemerintahan daerah tidak baik dan memberikan ketidakpastian kondisi pemerintahan daerah di masa mendatang. Pada kondisi tersebut, pemerintah daerah diduga cenderung untuk menutupi informasi tersebut guna menjaga agar legitimasi yang dimiliki tidak berkurang mengingat potensi persepsi bahwa pengelolaan pemerintahan daerah tidak dilaksanakan sebagaimana mestinya. Perona (2014) menunjukkan bahwa utang berpengaruh negatif terhadap tingkat transparansi pemerintah daerah. Berdasarkan uraian tersebut, hipotesis penelitian ini dirumuskan sebagai berikut:

$\mathrm{H}_{4}$ : Leverage berpengaruh negatif terhadap transparansi pemerintah daerah di Indonesia.

Ideologi dapat dimaknai sebagai cara berpikir seseorang atau suatu golongan, atau paham, teori, dan tujuan yang merupakan satu program sosial politik. UU Pemilihan Kepala Daerah mengatur bahwa pengusulan calon kepala daerah baik pada level pemerintahan provinsi (calon gubenur dan calon gubernur), pemerintahan kabupaten (calon bupati dan calon wakil bupati), dan pemerintahan kota (calon walikota dan calon wakil walikota) dapat menjadi peserta pemilihan ketika diusulkan oleh satu partai politik, atau diusulkan oleh beberapa/gabungan beberapa partai politik, atau calon kepala daerah tersebut mendaftarkan diri dan memenuhi pengajuan dirinya sebagai calon independen dalam pemilihan kepala daerah di Komisi Pemilihan Umum (KPU) berkenaan. Kondisi tersebut menimbulkan dinamika politik yang ditindaklanjuti oleh partai politik dengan melakukan koalisi dan negosiasi (Redjo 2010). Bentuk dinamika politik tersebut memunculkan tiga gabungan partai politik yang mendukung masing-masing calon yang mengikut pemilihan presiden dan wakil presiden tahun 2009. Dinamikan tersebut terjadi kembali pada pemilihan presiden tahun 2014, terdapat dua koalisi gabungan partai politik yang mendukung 2 calon yang berkompetisi, yaitu Koalisi Indonesia Hebat (KIH) dan Koalisi Merah Putih (KMP). Koalisi tersebut dirasakan tidak hanya di level pemerintah pusat, melainkan sampai ke tiap-tiap daerah di Indonesia. Dengan adanya kesamaan ideologi dalam berkoalisi mendukung pemerintahan yang ada baik di tingkat pusat maupun daerah, mengindikasikan keselarasan sistem nilai yang ada antara partai yang tergabung dalam koalisi dengan pemerintah yang berkuasa. Kondisi tersebut diduga dapat menurunkan usaha komunikasi yang dilakukan oleh pemerintah dalam memberikan informasi secara lebih transparan kepada masyarakat karena legitimasi akan terjaga dengan adanya kesamaan kesamaan keyakinan, kepercayaan, dan sistem nilai yang telah terwujud dan dipahami bersama. Piotrowski dan Gregg (2007) dan Sol (2013) menjelaskan bahwa ideologi berpengaruh terhadap transparansi pemerintah daerah. Berdasarkan uraian tersebut, hipotesis penelitian ini dirumuskan sebagai berikut:

$\mathrm{H}_{5}$ : Ideologi berpengaruh negatif terhadap transparansi pemerintah daerah di Indonesia. 
Undang-Undang Dasar 1945, Pasal 18 menyebutkan bahwa Gubernur, Bupati, dan Walikota masingmasing sebagai kepala pemerintah daerah provinsi, kabupaten, dan kota dipilih secara demokratis. UU Nomor 8 Tahun 2015 menjelaskan bahwa calon gubernur, calon wakil gubernur, calon bupati, calon wakil bupati, calon walikota, dan calon wakil walikota yang memperoleh suara terbanyak dalam pemilihan ditetapkan sebagai pasangan calon terpilih. Semakin tinggi tingkat dukungan masyarakat dimungkinkan meningkatkan dan menguatkan legitimasi atas kepercayaan absolut warga terhadap kepada daerah. Dalam kondisi tersebut, kepala daerah diduga akan menjadi lebih tidak transparan karena merasa telah mempunyai dukungan dan kepercayaan yang tinggi dari masyarakat. Sol (2013) menunjukkan bahwa kepala daerah yang memiliki tingkat kemenangan mayoritas akan menurunkan tingkat transparansi. Berdasarkan uraian tersebut, hipotesis penelitian ini dirumuskan sebagai berikut:

$\mathrm{H}_{6}$ : Tingkat kemenangan Kepala Daerah berpengaruh negatif terhadap transparansi Pemerintah Daerah di Indonesia.

Pengangguran merupakan suatu kondisi yang tidak dapat dihindari dalam kehidupan pemerintahan daerah. TPT menurut BPS adalah suatu persentase jumlah pengangguran terhadap jumlah angkatan kerja. Semakin tingginya tingkat pengangguran yang ada dalam masyarakat diduga semakin mengindikasikan bahwa kondisi yang buruk (distress) dalam masyarakat. Kondisi tersebut juga diduga semakin memperlihatkan bahwa pemerintah tidak dapat memenuhi tanggung jawab untuk memperluas kesempatan kerja dan menyerap pencari kerja dan/atau angkatan kerja yang mencoba mencari pekerjaan yang baru sebagaimana diamanahkan dalam Peraturan Pemerintah Nomor 33 Tahun 2013 tentang Perluasan Kesempatan Kerja. Kondisi yang memperlihatkan ketidakmampuan pemerintah tersebut diduga akan menurunkan legitimasi yang dimiliki oleh pemerintah daerah sehingga pemerintah mau tidak mau akan berusaha untuk menutupi kondisi yang ada dan menjadi kurang transparan dan mengkomunikasikan informasi mengenai hal dimaksud kepada berbagai pihak guna mengurangi ruang bagi masyarakat untuk mengetahui kondisi distress akibat tingginya pengangguran di suatu pemerintahan daerah. Caamano-Alegre et al. (2011) menjelaskan bahwa tingkat pengangguran berpengaruh negatif terhadap transparansi. Berdasarkan uraian tersebut, hipotesis penelitian ini dirumuskan sebagai berikut:

$\mathrm{H}_{7}$ : Tingkat pengangguran berpengaruh negatif terhadap transparansi pemerintah daerah di Indonesia.

Aktivitas ekonomi melibatkan produksi, distribusi, dan konsumsi barang dan jasa di semua tingkatan dalam masyarakat. Produk Domestik Bruto (PDB) merupakan salah satu indikator yang dapat digunakan untuk mengukur kegiatan dan aktivitas ekonomi yang ada saat ini dan maupun potensi/perkiraan di masa depan yang mempunyai dampak terhadap berbagai aspek perekonomian suatu negara. Adapun Produk Domestik Regional Bruto (PDRB) merupakan indikator yang lebih tepat digunakan untuk melihat kegiatan dan aktivitas ekonomi suatu daerah. Menurut Badan Pusat Statistik (2015), PDRB pada dasarnya merupakan gambaran atas seluruh jumlah nilai tambah yang tercipta dalam seluruh sektor ekonomi di suatu wilayah pemerintah daerah. Semakin tingginya PDRB dimaksud diduga menggambarkan wujud pengelolaan dan hasil kerja pemerintah daerah yang tinggi dalam mengelola sumber daya suatu daerah. Puspita dan Dwi (2012) menemukan bahwa kinerja yang tinggi berkorelasi dengan manajemen publik yang baik. Kondisi tersebut diduga merupakan indikator pengelolaan pemerintahan yang baik dan sesuai dengan sistem nilai yang ada dalam kontrak sosial antara pemerintah dan pihak yang terkait sehingga mendorong pemerintah daerah untuk mengkomunikasikan informasi terkait peningkatan PDRB kepada berbagai pihak secara lebih transparan dalam rangka meningkatkan legitimasi yang ada dalam pemerintahan daerah. Berdasarkan uraian tersebut, hipotesis penelitian ini dirumuskan sebagai berikut:

$\mathrm{H}_{8}$ : Aktivitas ekonomi berpengaruh postitif terhadap transparansi pemerintah daerah di Indonesia.

\section{Metoda Penelitian}

\section{Data dan Sampel}

Populasi dalam penelitian ini adalah seluruh pemerintah daerah di Indonesia tahun 2012-2015. Penelitian ini menggunakan sample frame berupa daftar pemerintah daerah di Indonesia yang memperoleh hasil penilaian pemeringkatan keterbukaan informasi publik pada badan publik yang dilakukan oleh Komisi Informasi, serta memiliki data rasio lansia, IPM, APBD, data pemilihan legislatif (DPRD), data pemilihan eksekutif (kepala daerah), tingkat pengangguran, dan PDRB. Pengambilan sampel dalam penelitian ini dilakukan dengan menggunakan tipe desain sampel metode nonpropability sampling berupa yaitu metode sampling purposive. Berdasarkan sample design yang digunakan, sample size dalam penelitian ini berupa 394 Pemerintah Daerah yang terdiri atas 245 Pemerintah Kabupaten, 99 Pemerintah Kota, dan 52 Pemerintah Provinsi. Rincian pengambilan sampel dalam penelitian ini disajikan pada Tabel 1. 
Tabel 1. Sampel Data

\begin{tabular}{lccccc}
\hline \multicolumn{1}{c}{ Uraian } & 2012 & 2013 & 2014 & 2015 & Jumlah \\
\hline Pemerintah daerah di Indonesia & 529 & 539 & 542 & 542 & 2.152 \\
Pemerintah daerah di Indonesia yang tidak memiliki nilai transparansi & -503 & -428 & -426 & -395 & -1.752 \\
Pemerintah daerah memiliki nilai transparansi dan data tidak lengkap & -1 & -2 & -1 & -2 & -6 \\
Jumlah & 25 & 109 & 115 & 145 & 394 \\
\hline
\end{tabular}

\section{Data dan Sampel}

Penelitian ini menggunakan data sekunder yang bersumber dari beberapa instansi pemerintahan dan media informasi yang tersedia. Adapun sumber data dalam penelitian ini meliputi data transparansi diperoleh dari Komisi Informasi. Data transparansi diperoleh dari Komisi Informasi. Data kependudukan (rasio lansia, IPM, tingkat pengangguran, dan PDRB) berasal dari BPS. Data keuangan (APBD) bersumber dari Kementerian Dalam Negeri dan Direktorat Jenderal Perimbangan Keuangan Kementerian Keuangan. Adapun data mengenai pemilihan legislatif daerah sebagai proxy ideologi dan data pemilihan eksekutif daerah yang digunakan sebagai proxy tingkat kemenangan kepala daerah diperoleh dari KPU. Selain itu, kebutuhan data-data tersebut juga didukung dengan informasi yang diperoleh melalui pencarian di internet pada situs yang memberitakan informasi mengenai data-data dimaksud.

\section{Definisi dan Pengukuran Variabel}

Definisi operasional dan pengukuran variabel dalam penelitian ini disajikan dalam Tabel 2.

Tabel 2. Definisi Operasional dan Pengukuran Variabel Penelitian

\begin{tabular}{|c|c|c|}
\hline Variabel & Pengukuran Variabel & Referensi \\
\hline $\begin{array}{l}\text { Tranparansi } \\
\text { pemerintah daerah } \\
(T R A N S P)\end{array}$ & $\begin{array}{l}\text { Nilai antara } 0 \text { s.d. } 100 \text { terhadap kepatuhan pelaksanaan pengelolaan informasi } \\
\text { publik sesuai Undang-Undang Nomor } 14 \text { Tahun } 2008 \text { tentang Keterbukaan } \\
\text { Informasi Publik. }\end{array}$ & $\begin{array}{l}\text { RI, UU Nomor } 14 \\
\text { Tahun 2008, (2008); } \\
\text { Komisi Informasi }\end{array}$ \\
\hline $\begin{array}{l}\text { Rasio Lansia } \\
(E L D E R L Y)\end{array}$ & $\begin{array}{l}\text { Jumlah penduduk yang telah mencapai usia lebih dari enam puluh tahun di suatu } \\
\text { pemerintah daerah dibagi jumlah penduduk suatu pemerintah daerah. }\end{array}$ & $\begin{array}{l}\text { Badan Pusat Statistik } \\
\text { (2015) }\end{array}$ \\
\hline $\begin{array}{l}\text { Indeks Pembangunan } \\
\text { Manusia (IPM) }\end{array}$ & $\begin{array}{l}\text { Rata-rata geometris (akar pangkat tiga) dari indeks kesehatan, indeks pendidikan, } \\
\text { dan indeks pengeluaran pemerintah daerah. }\end{array}$ & $\begin{array}{l}\text { Badan Pusat Statistik } \\
\text { (2015) }\end{array}$ \\
\hline $\begin{array}{l}\text { Derajat Desentralisasi } \\
\text { Fiskal }(R A S P A D)\end{array}$ & Total Pendapatan Asli Daerah (PAD) dibagi total pendapatan daerah. & Mahmudi (2016) \\
\hline Leverage (LEV) & Total kewajiban pemerintah daerah dibagi dengan total aset pemerintah daerah. & Mahmudi (2016) \\
\hline Ideologi (IDEOLOG) & $\begin{array}{l}\text { Variabel dummy nilai } 1 \text { adalah partai pemenang pemilu legislatif daerah yang } \\
\text { termasuk dalam koalisi pemerintah pusat, dan nilai } 0 \text { adalah partai pemenang pemilu } \\
\text { legislatif daerah yang bukan merupakan anggota koalisi pemerintah pusat. }\end{array}$ & $\begin{array}{l}\text { Kamus Besar Bahasa } \\
\text { Indonesia, (2016a); } \\
\text { Republik Indonesia } \\
\text { (2015) }\end{array}$ \\
\hline $\begin{array}{l}\text { Tingkat Kemenangan } \\
\text { kepala daerah } \\
(M A J O R)\end{array}$ & $\begin{array}{l}\text { Jumlah pemilih pasangan calon kepala daerah pemenang pilkada dibagi dengan } \\
\text { total pengguna hak pilih pada pilkada. }\end{array}$ & $\begin{array}{l}\text { Republik Indonesia } \\
(2015)\end{array}$ \\
\hline $\begin{array}{l}\text { Tingkat Pengangguran } \\
(\text { UNEMPLOYED) }\end{array}$ & $\begin{array}{l}\text { Total pengangguran pemerintah daerah dibagi dengan total angkatan kerja } \\
\text { pemerintah daerah. }\end{array}$ & $\begin{array}{l}\text { Badan Pusat Statistik } \\
\text { (2015) }\end{array}$ \\
\hline $\begin{array}{l}\text { Aktivitas Ekonomi } \\
(P D R B)\end{array}$ & 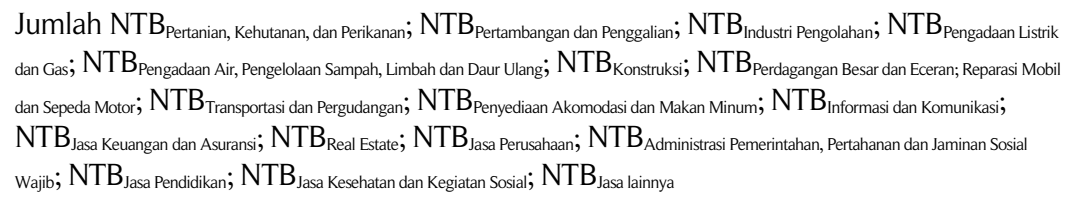 & $\begin{array}{l}\text { Badan Pusat Statistik } \\
\text { (2015) }\end{array}$ \\
\hline $\begin{array}{l}\text { Aset pemerintah } \\
\text { daerah }(A S S E T)\end{array}$ & Total aset pemerintah daerah. & $\begin{array}{l}\text { Republik Indonesia } \\
\text { (2010) }\end{array}$ \\
\hline $\begin{array}{l}\text { Periode } \\
\text { Kepemimpinan } \\
\text { Kaepala Daerah } \\
(P E R I O D E K A D A)\end{array}$ & $\begin{array}{l}\text { Variabel dummy berupa angka } 0 \text { apabila merupakan kepala daerah menjabat } \\
\text { periode pertama dan angka } 1 \text { apabila kepala daerah melaksanakan masa jabatan } \\
\text { periode kedua. }\end{array}$ & $\begin{array}{l}\text { Republik Indonesia } \\
\text { (2015) }\end{array}$ \\
\hline
\end{tabular}




\section{Metode Analisis Data dan Pengujian Hipotesis}

Penelitian ini menggunakan regresi data panel dengan persamaan seperti berikut ini.

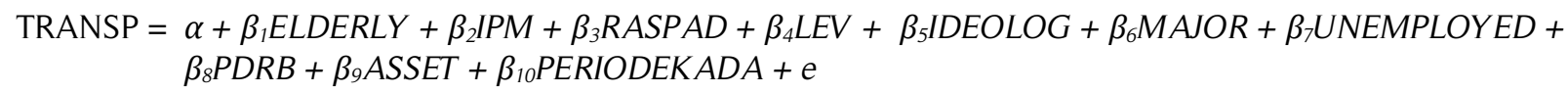

Keterangan:

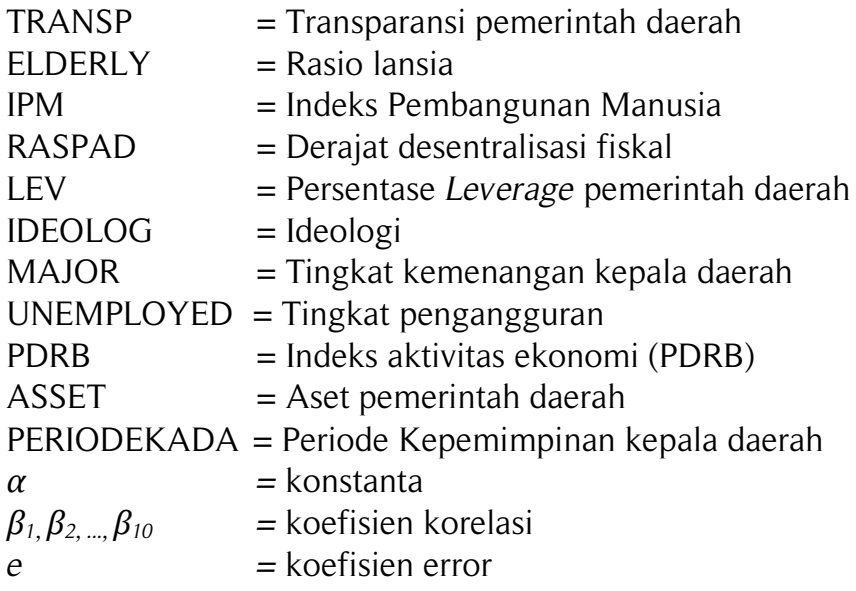

Mengingat data yang digunakan merupakan data lintas tahun atas Pemerintah Daerah di Indonesia, penelitian ini menggunakan metode regresi data panel. Adapun Teknik dan metode analisis data panel yang digunakan dalam penelitian ini meliputi pengujian model estimasi data panel, penentuan model estimasi dalam penelitian, penentuan kesesuaian model, penentuan koefisien determinasi model, dan pembahasan hasil pengujian hipotesis penelitian.

\section{Hasil dan Pembahasan}

\section{Statistik Deskriptif}

Hasil pengujian statistik deskriptif atas variabel penelitian disajikan pada Tabel 3.

Tabel 3. Statistik Deskriptif

\begin{tabular}{|c|c|c|c|c|c|}
\hline Variable & Obs & Mean & Std. Dev. & Min & Max \\
\hline TRANSP & 394 & 51,17 & 22,44 & 1,94 & 99,77 \\
\hline ELDERLY & 394 & 8,27 & 3,23 & 0,83 & 19,11 \\
\hline IPM & 394 & 68,89 & 5,68 & 39,41 & 83,25 \\
\hline RASPAD & 394 & 16,51 & 15,14 & 0,04 & 78,70 \\
\hline LEV & 394 & 1,15 & 1,97 & 0,00 & 17,9 \\
\hline IDEOLOG & 394 & 0,42 & 0,49 & 0,00 & 1,00 \\
\hline MAJOR & 394 & 50,05 & 12,17 & 24,26 & 93,47 \\
\hline UNEMPLOYED & 394 & 6,69 & 2,99 & 0,53 & 17,97 \\
\hline PDRB & 394 & 938,30 & 48,45 & 841,01 & $1.260,21$ \\
\hline ASSET & 394 & 753,043 & 94,134 & 664,115 & $2.251,42$ \\
\hline PERIODEKADA & 394 & 0,48 & 0,50 & 0,00 & 1,00 \\
\hline
\end{tabular}

Keterangan: TRANSP = Transparansi pemerintah daerah, ELDERLY = Rasio lanjut usia, IPM = Indeks Pembangunan Manusia, RASPAD = Derajat desentralisasi fiskal, LEV = Leverage, IDEOLOG = Ideologi, Major = Tingkat kemenangan kepala daerah, UNEMPLOYED = Tingkat pengangguran, PDRB = Aktivitas Ekonomi, ASSET $=$ Aset pemerintah daerah, PERIODEKADA $=$ Periode kepemimpinan kepala daerah

Tabel 3 menunjukkan bahwa rata-rata transparansi 394 pemerintah daerah selama kurun waktu tahun 2012 s.d. 2015 adalah 51,17 dengan standar deviasi 22,44. Transparansi tertinggi mencapai nilai 99,77, namun 
terdapat pemerintah daerah yang memiliki nilai transparansi 1,97. Hal ini menunjukkan bahwa transparansi masih rendah dari nilai maksimal seratus yang dapat diperoleh, rata-rata tingkat transparansi pemerintah daerah di Indonesia hanya sebesar 51,17. Dari sisi sosiodemografi, rata-rata rasio lansia pada 394 pemerintah daerah selama kurun waktu tahun 2012 s.d. 2015 menurut Tabel 3 tersebut adalah 8,27 dengan standar deviasi 3,22. Rasio lansia tertinggi mencapai $19,11 \%$, sedangkan rasio terkecil sebesar $0,83 \%$. Adapun rata-rata IPM adalah 68,89 . Disparitas IPM di Indonesia saat ini tinggi mengingat terdapat pemerintah daerah yang mencapai IPM 83,25 , namun di sisi lain terdapat pula pemerintah daerah yang hanya memiliki IPM sebesar 39,41. Gambaran dimensi fiskal pada Tabel 3 memperlihatkan bahwa rata-rata derajat desentralisasi fiskal pada 394 pemerintah daerah selama kurun waktu tahun 2012 s.d. 2015 adalah sebesar 16,51\%. Derajat desentralisasi fiskal tertinggi mencapai $78,70 \%$, sedangkan nilai terkecil sebesar adalah $0,04 \%$. Terkait dengan leverage, rata-rata leverage adalah $1,15 \%$ Rentang leveragepemerintah berkisar antara 0 s.d. 17,9.

Tabel 3 juga menunjukkan rata-rata persentase kemenangan kepala daerah dalam pemilihan kepala daerah di 394 pemerintah daerah selama kurun waktu tahun 2012 s.d. 2015 adalah 50,05 dengan standar deviasi 12,17. Selain itu, dari sisi Ideologi, terdapat sebaran hubungan ideologi pemerintah daerah dengan ideologi pemerintah pusat, yang digambarkan bahwa terdapat legislatif yang dipimpin oleh partai yang tergabung dalam koalisi, namun juga terdapat legislatif pemerintahan daerah yang dipimpin oleh partai yang menjadi oposisi terhadap pemerintah daerah. Adapun dimensi ekonomi tergambarkan dari rata-rata tingkat pengangguran di 394 pemerintah daerah selama kurun waktu tahun 2012 s.d. 2015 menurut Tabel 3 adalah 6,69. Tingkat pengangguran tertinggi mencapai $17,97 \%$, sedangkan tingkat pengangguran terendah sebesar $0,53 \%$. Selain itu, statistik deskriptif memperlihatkan bahwa rata-rata PDRB 394 pemerintah daerah adalah 93.832,77.

Sementara untuk korelasi data penelitian dapat dilihat dalam Tabel 4.

Tabel 4. Korelasi Data

\begin{tabular}{|c|c|c|c|c|c|c|c|c|c|c|c|}
\hline & TRANSP & ELDERLY & IPM & RASPAD & LEV & IDEOLOG & MAJOR & $\begin{array}{c}\text { UNEMPL } \\
\text { OYED }\end{array}$ & PDRB & ASSET & $\begin{array}{l}\text { PERIOD } \\
\text { EKADA }\end{array}$ \\
\hline TRANSP & 1.000 & & & & & & & & & & \\
\hline ELDERLY & 0.167 & 1.000 & & & & & & & & & \\
\hline IPM & 0.126 & $(0.085)$ & 1.000 & & & & & & & & \\
\hline RASPAD & 0.089 & $(0.177)$ & 0.283 & 1.000 & & & & & & & \\
\hline LEV & (0.004) & $(0.128)$ & $(0.015)$ & 0.261 & 1.000 & & & & & & \\
\hline IDEOLOG & $(0.017)$ & 0.182 & 0.164 & 0.190 & 0.007 & 1.000 & & & & & \\
\hline MAJOR & $(0.022)$ & 0.074 & 0.025 & $(0.073)$ & $(0.071)$ & $(0.048)$ & 1.000 & & & & \\
\hline NEMPLOYED & $(0.211)$ & $(0.390)$ & 0.011 & 0.005 & 0.041 & $(0.041)$ & $(0.020)$ & 1.000 & & & \\
\hline PDRB & 0.090 & $(0.044)$ & 0.103 & 0.751 & 0.197 & 0.151 & $(0.094)$ & 0.013 & 1.000 & & \\
\hline ASSET & 0.038 & $(0.086)$ & 0.153 & 0.366 & 0.001 & 0.092 & 0.014 & 0.058 & 0.571 & 1.000 & \\
\hline PERIODEKADA & $(0.097)$ & 0.039 & $(0.009)$ & (0.099) & $(0.078)$ & 0.121 & $(0.133)$ & 0.042 & $(0.049)$ & 0.065 & 1.000 \\
\hline
\end{tabular}

\section{Hasil Pengujian Hipotesis}

Penelitian ini menggunakan data panel dan pengolahan datanya melalui aplikasi stata. Proses pengujian hipotesis yang perlu dilakukan meliputi pengujian fixed effect dan random effect atas data, pengujian hausman test guna mengetahui metode yang digunakan dalam penelitian, dan pembahasan pengujian hipotesis. Hasil pengujian fixed effectModel (FEM) atas data transparansi pemerintah daerah di Indonesia, dapat dilihat pada Tabel 5.

Hasil pengujian hausman test menunjukkan nilai Prob>chi2 $=0.000$ sehingga model estimasi yang digunakan dalam penelitian adalah model fixed effect model.

$$
\begin{aligned}
\operatorname{chi2}(8) & =(\mathrm{b}-\mathrm{B})^{\prime}\left[\left(\mathrm{V}_{-} \mathrm{b}-\mathrm{V}_{-} \mathrm{B}\right)^{\wedge}(-1)\right](\mathrm{b}-\mathrm{B}) \\
& =46.23
\end{aligned}
$$

Prob $>$ chi $2=0.0000$ 
Tabel 5. Hasil Pengujian Hipotesis

\begin{tabular}{|c|c|c|c|c|c|}
\hline \multirow[b]{2}{*}{ Variable } & \multirow[b]{2}{*}{ Tanda } & \multicolumn{2}{|c|}{ Fixed EffectModel (FEM) } & \multicolumn{2}{|c|}{ Random Effect Model (REM) } \\
\hline & & Koefisien & $P>|t|$ & Koefisien & $P>|t|$ \\
\hline ELDERLY & - & 18,16 & $0,002^{a}$ & 1,02 & $0,025^{\mathrm{b}}$ \\
\hline IPM & - & 1,08 & 0,357 & 0,46 & $0,049^{b}$ \\
\hline RASPAD & + & 0,83 & $0,058^{c}$ & 0,01 & 0,954 \\
\hline LEV & + & 1,67 & $0,069^{c}$ & 0,09 & 0,875 \\
\hline IDEOLOG & + & 5,86 & $0,088^{c}$ & 3,05 & 0,197 \\
\hline MAJOR & + & 0,02 & 0,923 & 0,06 & 0,537 \\
\hline UNEMPLOYED & + & 2,52 & $0,007^{a}$ & 0,69 & 0,115 \\
\hline PDRB & + & 0,01 & $0,002^{\mathrm{a}}$ & 0,02 & 0,394 \\
\hline ASSET & + & 15,50 & 0,799 & 43,22 & 0,940 \\
\hline PERIODEKADA & - & 5,00 & 0,250 & 4,65 & $0,054^{c}$ \\
\hline \\
\hline \multicolumn{6}{|l|}{ R-sq } \\
\hline Within & & 0,1616 & & 0,0008 & \\
\hline Between & & 0,0204 & & 0,1369 & \\
\hline Overall & & 0,0106 & & 0,0874 & \\
\hline
\end{tabular}

Keterangan: Keterangan: TRANSP $=$ Transparansi pemerintah daerah, ELDERLY $=$ Rasio lanjut usia, IPM = Indeks Pembangunan Manusia, RASPAD = Derajat desentralisasi fiskal, LEV = Leverage, IDEOLOG = Ideologi, Major $=$ Tingkat kemenangan kepala daerah, UNEMPLOYED = Tingkat pengangguran, $P D R B=$ Aktivitas Ekonomi, ASSET $=$ Aset pemerintah daerah, PERIODEKADA = Periode kepemimpinan kepala daerah, $=$ signifikan pada level $0,01,:=$ signifikan pada level $0,05,=$ signifikan pada level 0,10 .

Berdasarkan hasil pengujian Fixed Effect Model (FEM) pada Tabel 5 diketahui bahwa model regresi linear berganda atas data panel dalam penelitian adalah fit, mengingat nilai Prob>F adalah 0,0002 (lebih kecil dari 0,005). Namun demikian, nilai $\mathrm{R}$ squared within sebesar 0,1616 menunjukkan bahwa model persamaan regresi hanya dapat menjelaskan variabel dependen sebesar $16,16 \%$, sedangkan sisanya sebesar $83,84 \%$ dijelaskan oleh variabel lain di luar penelitian. Sedangkan berdasarkan nilai R squared overall nilai yang diperoleh hanya sebesar $1,06 \%$ yang mengindikasikan bahwa model persamaan regresi hanya dapat menjelaskan variabel dependen sebesar $1,06 \%$, sedangkan sisanya sebesar $88,94 \%$ dijelaskan oleh variabel lain di luar penelitian. Hasil tersebut bermakna bahwa walaupun model persamaan regresi dalam penelitian adalah valid, namun dalam praktisnya masih perlu penggalian berbagai variabel di luar penelitian yang diduga berpengaruh terhadap transparansi pemerintah daerah di Indonesia.

Tabel 5 tersebut menunjukkan bahwa variabel rasio lansia (ELDERLY) berpengaruh negatif terhadap transparansi pemerintah daerah di Indonesia, yaitu ditunjukkan oleh nilai $\mathrm{P}>|\mathrm{t}| \mathrm{sebesar}$ 0,002 (lebih kecil dari 0,010). Oleh karena itu, hipotesis pertama penelitian (H1) ditolak. Hasil tersebut bertentangan dengan hasil Esterller-More dan Jose (2012) yang mendapati bahwa pemerintah daerah dengan tingkat persentase lansia yang tinggi berkorelasi dengan tingginya transparansi, serta hasil Piotrowski dan Gregg (2007) yang juga memperoleh hasil yang serupa bahwa orang tua tampak lebih cenderung menginginkan transparansi daripada orang yang lebih muda.

Namun demikian, hasil penelitian menunjukkan bahwa karakteristik usia lanjut di Indonesia diduga menurunkan tingkat transparansi. Hal ini mungkin terkait dengan adanya persepsi negatif terhadap lansia mengenai lansia baik dari sisi biologi, ekonomi, maupun sosial sebagaimana dijelaskan oleh BPS. Secara biologis, lansia akan mengalami proses penuaan secara terus menerus yang ditandai dengan penurunan daya tahan fisik dan rentan terhadap serangan penyakit. Secara ekonomi, umumnya lansia lebih dipandang sebagai beban daripada sumber daya. Adapun secara sosial, kehidupan lansia sering dipersepsikan secara negatif, atau tidak banyak memberikan manfaat bagi keluarga dan masyarakat.

Adanya persepsi negatif bahwa lansia merupakan beban dalam masyarakat diduga dapat meningkatkan stigma bahwa kondisi masyarakat, termasuk pemerintahan dalam mengelola masyarakat menjadi kurang baik. Di sisi lain, pemerintah daerah berharap dapat menjaga legitimasi yang ada mengurangi komunikasi atas kondisi yang kurang baik dan dapat mengurangi legitimasi. Kondisi tersebut diduga menyebabkan pemerintah daerah akan menjadi kurang transparan dengan semakin meningkatnya rasio lansia di daerah.

Tabel 4 menunjukkan bahwa variabel IPM (IPM) tidak berpengaruh terhadap transparansi, yaitu ditunjukkan oleh nilai $\mathrm{P}>\mid \mathrm{tl}$ sebesar 0,357 (lebih besar dari 0,10). Hasil tersebut menunjukkan bahwa hipotesis kedua penelitian (H2) ditolak. Hasil tersebut diduga karena pada kenyataannya perhatian masyarakat Indonesia terhadap pemerintahan masih cukup rendah. Padahal informasi pemerintahan memberikan gambaran bagaimana 
pengelolaan segala sumber daya yang ada pada pemerintah. Salah satu indikator bahwa perhatian tersebut masih sangat kecil adalah data yang dipublikasikan oleh publikasi Asosiasi Penyelenggara Jasa Internet Indonesia (APJII) dalam Profil Pengguna Internet Indonesia (APJII 2015), yang menjabarkan bahwa sektor/kategori pemerintahan hanya mencapai porsi akses sebesar 7,0\% dari total aktivitas akses pengguna internet. Hal tersebut merupakan salah satu gambaran bahwa kondisi masyakarat di Indonesia saat ini belum menekankan pentingnya hubungan komunikasi dan perhatian atas apa yang dilakukan oleh pemerintahan. Dengan demikian, tinggi atau rendahnya IPM masyarakat yang meliputi komponen kualitas hidup, yaitu umum panjang dan sehat, pengetahuan, dan kehidupan yang layak, tidak serta merta akan meningkatkan tuntutan masyarakat atas transparansi informasi pemerintahan oleh pemerintah daerah. Di sisi lain, pemerintah daerah kemudian diduga tidak menyajikan informasi dan komunikasi yang maksimal mengenai pengelolaan pemerintahan, mengingat gambaran survei tersebut memperlihatkan bahwa masih rendahnya perhatian masyarakat atas pemerintahan.

Variabel derajat desentraliasasi fiskal (RASPAD) dalam Tabel 5 berpengaruh positif terhadap transparansi pemerintah daerah di Indonesia. Hal tersebut ditunjukkan oleh nilai P>ltl sebesar 0,058 (lebih kecil dari 0,10). Oleh karena itu, hipotesis ketiga penelitian (H3) diterima. Hasil tersebut selaras dengan dengan penjelasan Mahmudi (2016) bahwa semakin tinggi kontribusi PAD, maka semakin tinggi kemampuan daerah dalam penyelenggaraan desentralisasi. Hasil ini juga mendukung hasil Wahyudi dan Laila (2013) yang menyatakan bahwa terdapat korelasi positif antara kualitas derajat desentralisasi dan kualitas pemerintahan, mengingat tingginya derajat desentralisasi fiskal merupakan salah satu gambaran kinerja yang tinggi dari pemerintah daerah. Kondisi tersebut merupakan kondisi yang diharapkan oleh pemerintah daerah yang akan segera berusaha dikomunikasikan kepada masyarakat guna meningkatkan legitimasi atas pengelolaan penyelenggaraan pemerintahan daerah.

Terkait dengan variabel leverage, Tabel 4 memperlihatkan bahwa leverage (LEV) berpengaruh positif terhadap transparansi pemerintah daerah di Indonesia. Hal tersebut ditunjukkan oleh nilai P>|t| sebesar 0,069 (lebih kecil dari 0,10). Oleh karena itu, hipotesis keempat penelitian (H4) ditolak. Hal tersebut dapat dijelaskan dari perpektif bahwa kondisi entitas dengan leverage dapat diartikan sebagaimana dijelaskan oleh Mahmudi (2016) bahwa entitas kurang atau tidak memiliki kemampuan untuk melunasi utang. Hal tersebut diduga meningkatkan perhatian para kreditur untuk memperoleh segala informasi yang harus dipublikasikan oleh pemerintah daerah. Kondisi tersebut juga didukung oleh konsep yang ada pada Peraturan Pemerintah Nomor 60 Tahun 2008 tentang Sistem Pengendalian Intern Pemerintah bahwa dalam kondisi lingkungan pengendalian dalam hal ini adalah kondisi pemerintah daerah yang memiliki tingkat leverage yang semakin tinggi, risiko yang dihadapi baik oleh pemerintah daerah maupun kreditor menjadi semakin tinggi sehingga tindakan/aktivitas pengendalian dan bentuk komunikasi atas informasi yang tersedia akan semakin intens dan lebih komprehensif. Dengan demikian, semakin tinggi leverage, tuntutan kreditur atas informasi semakin besar, dan semakin tinggi transparansi sebagai bentuk komunikasi dalam rangka tetap menjaga legitimasi pemerintah daerah kepada para kreditur.

Tabel 5 menunjukkan bahwa ideologi (IDEOLOG) berpengaruh positif terhadap transparansi, yaitu ditunjukkan oleh nilai P>lt| sebesar 0,088 (lebih kecil dari 0,10). Hal tersebut menunjukkan bahwa hipotesis kelima penelitian (H5) ditolak. Hal ini diduga terjadi karena DPRD merupakan wakil rakyat yang dipilih melalui pemilihan umum legislatif. Sebagaimana dijelaskan oleh Vivanews (2016) bahwa kondisi saat ini terdapat ketidaksinkronan antara pimpinan DPR dan pimpinan DPRD, di mana pimpinan DPRD dipilih berdasarkan suara terbanyak, sedangkan pimpinan DPR dipilih bukan berdasarkan suara partai pemenang pemilu legislatif. Dengan kondisi tersebut dan juga adanya perbedaan dalam partai pengusung suatu calon presiden dan kepala daerah, maka diduga guna memperoleh legitimasi baik di tingkat daerah dan tingkat pusat, partai akan semakin mengkonsolidasikan diri dengan berkinerja lebih baik dalam menjalankan prioritas tugas dan tanggung jawabnya sebagaimana diatur dalam Undang-Undang Nomor 17 Tahun 2014 tentang MPR, DPR, DPD, dan DPRD, salah satunya tugas pengawasan terhadap implementasi berbagai aturan yang telah ditetapkan, termasuk aturan mengenai keterbukaan informasi publik sesuai UU KIP. Oleh karena itu, tuntutan terhadap transparansi mau tidak mau akan memaksa pemerintah daerah untuk mengkomunikasikan informasi mengenai penyelenggaraan pemerintahan daerah secara lebih transparan guna menjaga legitimasi pemerintahan (Licht et al. 2014).

Variabel tingkat kemenangan kepala daerah $(M A J O R)$ ditunjukkan dalam Tabel 5 bahwa tidak berpengaruh terhadap transparansi pemerintah daerah di Indonesia. Hal tersebut ditunjukkan oleh nilai $\mathrm{P}>|\mathrm{t}|$ sebesar 0,923 (lebih besar dari 0,10). Oleh karena itu, hipotesis keenam penelitian (H6) ditolak. Hasil tersebut bertentangan dengan hasil Sol (2013) menunjukkan bahwa kepala daerah yang memiliki tingkat kemenangan mayoritas akan menurunkan tingkat transparansi. Hal ini diduga terjadi karena realitas yang ada dalam masyarakat saat ini menggambarkan bahwa terdapat perbedaan antara janji-janji politik yang disampaikan oleh pasangan calon dengan realitas yang ada, salah satunya termasuk mengenai pengelolaan pemerintahan yang transparan (Beritasatu 2015). Hal tersebut diduga mengindikasikan bahwa tingkat kemenangan tidak 
berpengaruh secara langsung terhadap realitas penyelenggaraan transparansi pemerintah daerah. Selain itu, adanya klausul pemakzulan/pemberhentian terhadap kepala daerah sebagaimana diatur dalam UU Pemerintahan Daerah di mana salah satunya mengatur terkait ketidaktaatan terhadap seluruh ketentuan peraturan perundangundangan, diduga juga mempengaruhi perilaku kepala daerah untuk tetap menjaga komunikasi demi menjaga legitimasi dari pihak terkait yang dapat berarti tingkat transparansi dipertahankan pada tingkat tertentu.

Tabel 5 menunjukkan bahwa variabel tingkat pengangguran (UNEMPLOYED) berpengaruh positif terhadap transparansi, yaitu ditunjukkan oleh nilai P>ltl sebesar 0,007 (lebih kecil dari 0,010). Oleh karena itu, hipotesis ketujuh penelitian (H7) ditolak. Hasil tersebut bertentangan dengan hasil Caamano-Alegre et al. (2011) yang menunjukkan bahwa tingkat pengangguran berpengaruh negatif terhadap transparansi. Hal ini diduga terjadi karena tingkat pengangguran yang tinggi merupakan berita yang baik bagi pasar dalam kondisi ekonomi yang ekspansif sebagaimana dijelaskan Boyd, Jian, dan Ravi (2005). Kondisi ekonomi ekspansi merupakan gambaran kondisi Indonesia saat ini, di mana pemerintah berkomitmen untuk mempercepat pembangunan di Indonesia (Kementerian Energi dan Sumber Daya Mineral 2016), bahkan kebutuhan dana untuk menyelesaikan berbagai target pembangunan mencapai Rp4.900 triliun (Medan Bisnis Daily 2016). Dengan mempertimbangkan bahwa tingginya tingkat pengangguran yang dapat menjadi kabar bagus dalam ekonomi ekspansi, pemerintah diduga akan berupaya untuk mengkomunikasikan informasi tersebut kepada pasar dan masyarakat sehingga kondisi tidak full employement karena adanya unemployement tersebut dapat diketahui dan masyarakat yang termasuk dalam unemployement dapat dimanfaatkan untuk menyelesaikan berbagai program pembangunan yang telah ditetapkan.

Tabel 5 menunjukkan bahwa variabel aktivitas ekonomi (PDRB) berpengaruh positif terhadap transparansi pemerintah daerah di Indonesia, yaitu ditunjukkan oleh nilai P>lt| sebesar 0,002 (lebih kecil dari 0,010). Oleh karena itu, hipotesis kedelapan penelitian (H8) diterima. Hasil tersebut memperlihatkan bahwa apabila PDRB sebagai salah satu indikator aktivitas ekonomi dalam keadaan ekonomi yang baik, pemerintah daerah akan transparan dalam menyampaikan informasi kepada para stakeholders-nya guna menghindari adanya kecurigaan yang berlebih kepada pemerintah daerah dalam penyelenggaraan pemerintahan daerah dan menunjukkan bahwa pemerintah daerah telah mengelola daerah secara efektif dan efisien. Hal tersebut diharapkan dapat menjaga dan meningkatkan legitimasi atas pemerintah daerah.

Terkait dengan variabel kontrol, Tabel 5. menunjukkan bahwa baik variabel aset pemerintah daerah (ASSET) maupun variabel periode kepemimpinan kepala daerah (PERIODEKADA) tidak berpengaruh terhadap transparansi pemerintah daerah karena nilai $\mathrm{P}>|\mathrm{t}|$ lebih besar dari 0,10, yaitu nilai $\mathrm{P}>|\mathrm{t}|$ ASSET sebesar 0,799, sedangkan nilai $\mathrm{P}>|\mathrm{t}|$ PERIODEKADA sebesar 0,250.

\section{Simpulan}

Penelitian ini bertujuan untuk menguji faktor-faktor sosiodemografi, fiskal, institusional, dan ekonomi terhadap transparansi pemerintah daerah di Indonesia. Hasil pengujian atas hipotesis yang telah disusun menunjukkan bahwa variabel rasio lansia berpengaruh negatif terhadap transparansi pemerintah daerah di Indonesia. Variabel derajat desentralisasi fiskal, leverage, ideologi, tingkat pengangguran, dan aktivitas ekonomi berpengaruh positif terhadap transparansi pemerintah daerah di Indonesia. Adapun variabel Indeks Pembangunan Manusia (IPM) dan tingkat kemenangan kepala daerah tidak berpengaruh terhadap transparansi pemerintah daerah di Indonesia. Hasil pengujian tersebut menunjukkan bahwa hanya hipotesis ketiga (H3) dan hipotesis keenam (H6) yang diterima, yaitu hipotesis yang menyatakan bahwa derajat desentralisasi fiskal berpengaruh positif terhadap transparansi pemerintah daerah di Indonesia, serta aktivitas ekonomi berpengaruh postitif terhadap transparansi pemerintah daerah di Indonesia. Adapun hipotesis lainnya tidak diterima dalam penelitian ini.

Keterbatasan yang dihadapi dalam penelitian ini adalah terbatasnya pengetahuan penulis dalam menggali faktor-faktor yang diduga berpengaruh terhadap transparansi pemerintah daerah, mengingat luasnya cakupan faktor-faktor yang dapat berpengaruh dalam transparansi pemerintah daerah. Selain itu, adanya keterbatasan data transparansi pemerintah daerah di Indonesia karena pemeringkatan keterbukaan informasi publik pada badan publik belum dilakukan oleh seluruh Komisi Informasi dan belum dilaksanakan secara konsisten setiap tahun guna menentukan hasil penilaian atas pemeringkatan keterbukaan informasi publik pada badan publik, mengingat adanya keterbatasan anggaran dan sumber daya pada masing-masing Komisi Informasi, serta belum adanya peraturan mengenai petunjuk teknis secara nasional atas pelaksanaan evaluasi pemeringkatan keterbukaan informasi publik pada badan publik oleh Komisi Informasi. Keterbatasan lainya berupa keterbatasan data tingkat kemenangan kepala daerah, tingkat pengangguran, dan PDRB karena tidak selalu dipublikasikan oleh lembaga berwenang (KPU dan BPS) dan/atau sudah mengajukan permohonan data kepada lembaga berwenanga dimaksud, namun sampai dengan penyusunan penelitian belum mendapatkan jawaban. Hal tersebut dapat mengakibatkan perbedaan hasil pengujian jika data yang diperlukan dapat diperoleh secara lengkap. 


\section{Daftar Referensi}

Adzani, A. H., dan M. Dwi. 2014. Pengaruh kesejahteraan masyarakat, faktor politik, dan ketidakpatuhan regulasi terhadap opini audit laporan keuangan pemerintah daerah. Simposium Nasional Akuntansi XVII. Lombok, 24-27 September 2014.

Araujo, J. F. F. E. D., dan T. Fransisco. 2016. Local government transparency index: determinants of municipalities' rankings. International Journal of Public Sector Management 29 (4):327-347.

APJII. 2015. Profil pengguna internet indonesia 2014. Jakarta: Asosiasi Penyelenggara Jasa Internet Indonesia. Diakses dari https://apjii.or.id/downfile/file/PROFILPENGGUNAINTERNETINDONESIA2014.pdf

Badan Pusat Statistik. 2015. Proyeksi penduduk kabupaten/kota tiap-tiap provinsi di Indonesia 2010-2020. Jakarta: Badan Pusat Statistik.

Behn, B. K., L. Jing, dan D. Del. 2010. The determinants of transparency in nonprofit organizations: an exploratory study. Advances in International Accounting 26:6-12.

Beritasatu.com. 2015. Rendahnya partisipasi publik akibat realitas politik. Diakses dari http://www.beritasatu.com/pilkada/330230-rendahnya-partisipasi-publik-akibat-realitas-politik.html.

Bolivar, M. P. R., L. A. Munoz, dan A. M. L. Hernandez. 2013. Determinants of financial transparency in government. International Public Management Journal 16 (4):557-602.

Boyd, J. H., H. Jian, dan J. Ravi. 2005. The stock market's reaction to unemployement news: why bad news is usually good for stocks. The Journal of Finance, American Finance Association 60 (2):649-672.

Caamano-Alegre, J., L. Santiago, R. Francisco, dan S. Aurora. 2011. Budget transparency in local governments: an empirical analysis. International Studies Program Working Paper 11 (02):1-30.

Colquhoun, P. 2013. Political dan organizational legitimacy of public sector auditing in New Zealand local government. Accounting History 18 (4):473-489.

Dowling, J., dan P. Jeffrey. 1975. Organizational legitimacy: social values and organizational behaviour. The Pacific Sociological Review 18 (1):122-136.

Esterller-More, A., dan P. O. Jose. 2012. Fiscal transparency. Public Management Review 14 (8):1153-1173.

Guillamon, M., B. Frasisco, dan B. Bernardino. 2011. The determinants of local government's financial transparency. Local Government Studies 37 (4):391-406.

Indonesia Corruption Watch. 2014. Refleksi 5 tahun UU KIP informasi publik masih dipilih-pilih. Diakses dari https://antikorupsi.org/id/news/refleksi-5-tahun-uu-kip-informasi-publik-masih-\%E2\%80\%98dipilihpilih\%E2\%80\%99

Kamus Besar Bahasa Indonesia. 2016a. Ideologi. Kamus Besar Bahasa Indonesia. 2016.

2016b. Institutional. Kamus Besar Bahasa Indonesia. 2016.

Kamus Bisnis. 2016a. Aktivitas Ekonomi. Kamus Bisnis. 2016.

2016b. Economy. Kamus Bisnis. 2016.

Kementerian Energi dan Sumber Daya Mineral. 2016. Pemerintah dorong percepatan pembangunan Indonesia. Diakses dari https://migas.esdm.go.id/post/read/pemerintah-dorong-percepatan-pembangunan-di-indonesia

Kontan.co.id. 2014. Orang kerap lupa pasangan saat rencanakan pensiun. Diakses dari http://personalfinance.kontan.co.id/news/orang-kerap-lupa-pasangan-saat-rencanakan-pensiun.

Krina, L.L.P. 2003. Indikator dan alat ukur prinsip akuntabilitas, transparansi dan partisipasi. Jakarta: Sekretariat Good Governance Badan Perencanaan Pembangunan Nasional.

Kuswanto, G. 2012. Pelaksanaan good governance di Indonesia. Diakses dari https://www.banyumaskab.go.id/read/15538/pelaksanaan-good-governance-di-indonesia\#.W1uGqugzbIU.

Licht, J. D. F., D. Naurin, P. Esaiasson, dan M. Gilljam. 2014. When does transparency generate legitimacy? experimenting on a context-bound relationship. Governance: An International Journal of Policy, 
Administration, and Institutions 27 (1):111-34.

Mahmudi. 2016. Analisis laporan keuangan pemerintah daerah. Yogyakarta: UPP STIM YKPN.

Mardiasmo. 2002. Akuntansi sektor publik. Yogyakarta: Penerbit Andi.

Martani, D., F. Debby, dan Annisa. 2013. Transparansi keuangan dan kinerja pada website pemerintah daerah kabupaten/kota di Indonesia. Proceeding PESAT (Psikologi, Ekonomi, Sastra, Arsitektur \& Teknik Sipil). Bandung, 8-9 Oktober 2013.

Medan Bisnis Daily. 2016. 2016, Indonesia butuh dana Rp4.900 Triliun. Diakses dari http://www.medanbisnisdaily.com/news/read/2016/07/22/246747/2016-indonesia-butuh-dana-rp-4900triliun/.

Merriam Webster. 2016a. Fiscal. Merriam Webster. 2016.

2016b. Sociodemografic. Merriam Webster. 2016.

Perona, P. G. 2014. Budget transparency in local governments. Universitat Jaume I, Spain. Diakses dari http://repositori.uji.es/xmlui/bitstream/handle/10234/98608/TFG_2014_Gim\%C3\%A9nezPeronaP.pdf;se quence $=1$

Piotrowski, S. J., dan G. V. R. Gregg. 2007. Citizen attitudes toward transparency in local government. The American Review of Public Administration 37 (3):306-323.

Puspita, R., dan M. Dwi. 2012. Analisis pengaruh kinerja dan karakteristik Pemda terhadap tingkat pengungkapan dan kualitas informasi dalam website Pemda. Simposium Nasional Akuntansi XV, Banjarmasin, 20-23 September 2012..

Redjo, S. I. 2010. Koalisi dalam sistem pemerintahan. Governance 1 (1):32-39.

Republik Indonesia. 1945. Undang-undang dasar 1945. Republik Indonesia.

1998. Undang-undang nomor 13 tahun 1998 tentang kesejahteraan lanjut usia. Republik Indonesia.

1999. Undang-undang nomor 22 tahun 1999 tentang pemerintahan daerah. Republik Indonesia.

2005. Peraturan pemerintah nomor 58 tahun 2005 tentang pengelolaan keuangan daerah. Republik Indonesia.

2008. Undang-undang nomor 14 tahun 2008 tentang keterbukaan informasi publik. Republik Indonesia.

2010. Peraturan pemerintah nomor 71 tahun 2010 tentang standar akuntansi pemerintahan. Republik Indonesia.

—. 2011. Peraturan pemerintah nomor 30 tahun 2011 tentang pinjaman daerah. Republik Indonesia.

2014. Undang-undang nomor 23 tahun 2014 tentang pemerintahan daerah. Republik Indonesia.

2015a. Undang-undang nomor 8 tahun 2015 tentang perubahan atas undang-undang nomor 1 tahun 2015 tentang penetapan peraturan pemerintah pengganti undang-undang nomor 1 tahun 2014 tentang pemilihan gubernur, bupati, dan walikota menjadi undang-undang. Republik of Indonesia.

—. 2015b. Undang-undang nomor 9 tahun 2015 tentang perubahan kedua atas undang-undang nomor 23 tahun 2014 tentang pemerintahan daerah. Republik Indonesia.

Serrano-Cinca, C., R. Mar, dan P. Pilar. 2009. Factors influencing E-disclosure in local public administrations. Environment and Planning C: Government and Policy 27 (2): 355-378.

Sheng, Y. K. 2009. What is good governance? United Nations: Economic and Social Commision for Asia and The Pasific.

Sofia A., dan H. Bagus. 2013. Analisis transparansi dan akuntabilitas pemerintah daerah melalui pengungkapan informasi pada website. Jurnal Manajemen Indonesia 12 (4): 297-308.

Sol, D. A. D. 2013. The institutional, economic and social determinants of local government transparency. Journal of Economic Policy Reform 16 (1): 90-107.

Suchman, M. C. 1995. Managing legitimacy: strategic and institutional approaches. The Academy of 
Management Review 20 (3): 571-610.

Tavares, A. F., dan F. D. C. Nuno. 2014. The determinants of local government transparency: a preliminary analysis. ICEGOV2014-8th International Conference on Theory and Practice of Electronic Governance. Guimaraes, Portugal, 27-30 Oktober 2014.

Komisiinformasi.go.id. 2016. Wakil ketua KIP: keterbukaan informasi membutuhkan MAKO (lima komitmen). Diakses dari https://www.komisiinformasi.go.id/news/view/wakil-ketua-kip-keterbukaan-informasimembutuhkan-mako-lima-komitmen.

Vivanews. 2016. Revisi UU, mekanisme pengisian kursi pimpinan DPR diubah. Diakses dari https://www.viva.co.id/berita/politik/849338-revisi-uu-mekanisme-pengisian-kursi-pimpinan-dpr-diubah.

Wehner, J., dan D. R. Paolo. 2013. Citizens, legislators, and executive disclosure: the political determinants of fiscal transparency. World Development 41: 96-108. 